\title{
Roads to recovery: an investigation of early medieval agrarian strategies in Byzantine Italy in and around the eighth century
}

\author{
Paul Arthur ${ }^{1}$, Girolamo Fiorentino ${ }^{2} \&$ Anna Maria Grasso $^{2,3}$
}

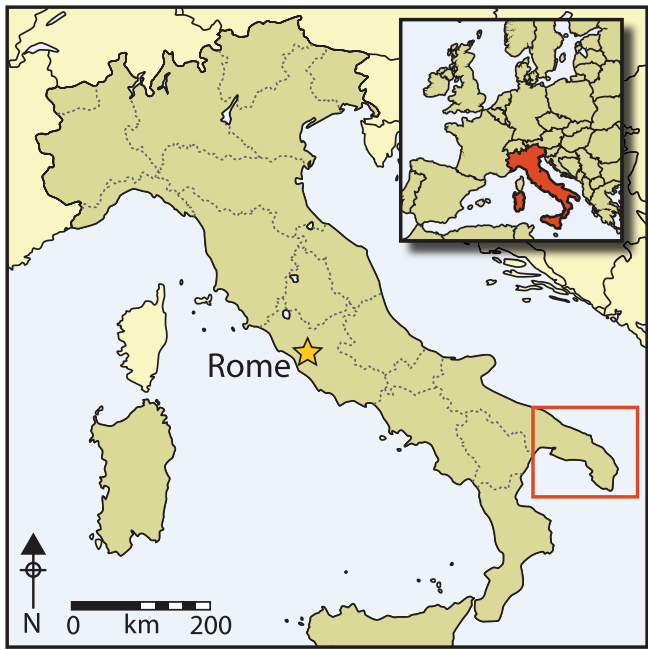

The cumulative power of botanical and chemical analysis is demonstrated here by our authors, who succeed in opening a window on Europe's most obscure period, in the south as in the north, the time after the Roman and then the Byzantine empire lost its hold. The emphasis here is on the rise in production and trade of cash crops in the eighth century as detected by survey, pollen, charcoal and residues. Taken together, the new data show a community well on the road to economic recovery after two centuries of recession and monetary failure.

Keywords: Italy, Byzantium, eighth century AD, economic recovery

\section{Introduction}

The eighth century was historically momentous for Byzantium. It witnessed the definitive rise of Arab power in the Mediterranean and the Middle East, and the consequent waning of Byzantine power and influence. In Italy, Byzantine Ravenna fell to the Lombards in AD 751, Rome and Naples gained independence, and by the end of the century Charlemagne had established his own 'Roman' empire, which was to include much of the northern and central part of the peninsula. The Italian territory of Byzantium was to be reduced substantially to Sicily and to the southerly parts of modern Calabria and Apulia. The Byzantine monetary economy had ceased throughout much of the empire and trade was at an all-time low.

1 Laboratory of Medieval Archaeology, University of Salento, Via D. Birago 64, 73100 Lecce, Italy (Email: paul.arthur@unisalento.it)

2 Laboratory of Archaeobotany and Palaeoecology, University of Salento, Via D. Birago 64, 73100 Lecce, Italy (Email: girolamo.fiorentino@unisalento.it)

3 Dipartimento di Archeologia e Storia delle Arti, Università di Siena, Via Roma 56, 53100 Siena, Italy (Email: grasso13@unisi.it) 
Constantinople itself was racked by religious strife as iconoclasm came to the fore, bringing with it intolerance, witch-hunts and emigration to Italy and to other outlying provinces. The history of this tortured and imperfectly understood century, fundamental for our understanding of a new order following the demise of antiquity, has recently been made the subject of a major study by Leslie Brubaker and John Haldon (2011). Their comprehensive work on the story so far makes it quite clear that the immense reservoir of archaeological and environmental data, regarding the rebirth of the Mediterranean economy after the collapse of Roman imperialism, is still largely to be tapped.

Now, in the Salento (southern Apulia), the very heel of Italy and a far-flung western territory of the Byzantine empire, archaeology is beginning to tell a story of local survival and gradual growth in and around the eighth century, with the new exploitation of natural resources in a demonstrably changing environment.

\section{Background}

From the later sixth century, Italy's main link to the Eastern empire became the ancient port-town of Otranto (Hydruntum). It effectively replaced Brindisi (Brundisium) which, before the Balkan peninsula had been overrun by the Slavs, had linked the ancient Via Appia, by means of a short sea-haul across the Adriatic, with the Via Egnatia, which ran from Durres (Dyrrhachium) to Constantinople. Although Otranto itself had briefly succumbed to the Lombards of Benevento in the mid eighth century, reference is made by the Lombard historian Paul the Deacon to its international trade in the latter years of the same century (Hist. Lang. II.21; Bethman \& Waitz 1878; on Otranto at this time see now Von Falkenhausen 2007). Indeed, around the same years as Paul was writing, a kiln site was established close to Otranto's port basin in order to produce amphorae, probably intended for exportation to sites across the Adriatic such as Butrint and Corinth. Perhaps they contained local wine. Indeed, gas chromatography on similar vessels from a Byzantine village at Supersano, south of Lecce, to which we shall later return, has yielded traces of pine resin and, in one case, through infrared spectrophotometry, calcium tartrate, a by-product of wine manufacture (Arthur et al. 2008: 372). Nevertheless, the question of contents remains open, as somewhat similar globular amphorae from the ninth-century shipwreck of Bozburun, off south-west Turkey, have yielded both olive stones and grape seeds (Hocker 1998).

Unlike much of the Salento at this time, the immediate hinterland of Otranto must have been particularly well-watered and fertile (Figure 1). Of the two small valleys behind the town, one, the Valle dell'Idro, was irrigated by a natural spring called le sorgenti di Carlo Magno, attributed by local legend to the direct intervention of Charlemagne. Though he is not known to have acted at Otranto, the use of his name might suggest that engineering works on the spring line took place between the later eighth and early ninth centuries.

\section{Sites and resources in the eighth century}

To the north of Otranto, field survey around the Alimini Lakes in 2009 brought to light a number of small farms or villages that testify to the opening-up of land that would appear to have been largely deserted and overgrown with Mediterranean macchia in classical

(C) Antiquity Publications Ltd. 


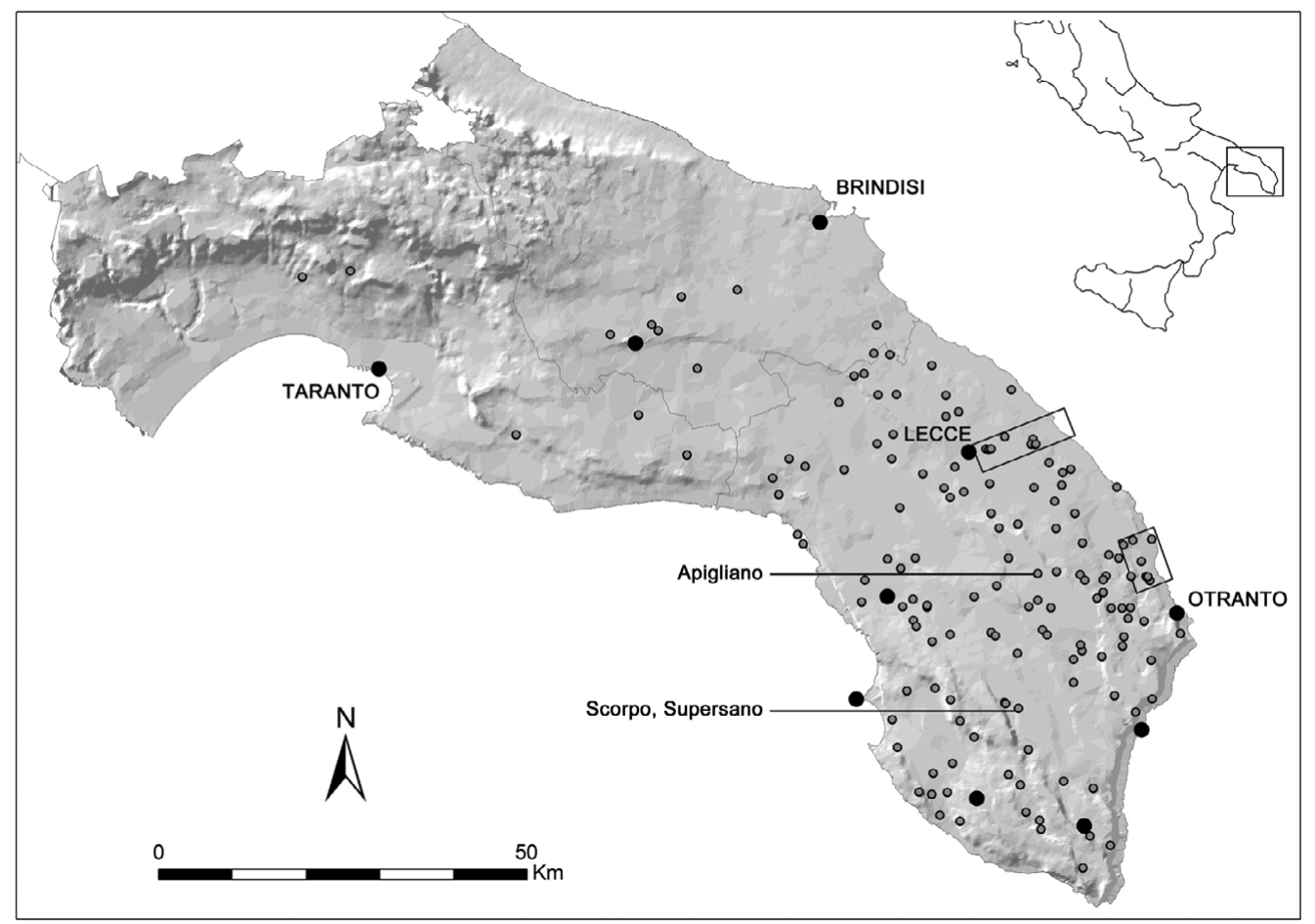

Figure 1. Current knowledge of Byzantine site distribution in the Salento. Surveyed areas east of Lecce and around the Alimini Lakes are outlined.

times (Figure 2). Excavation by the authors of one of these sites in 2010 has demonstrated occupation from at least the eighth-ninth centuries, as well as the construction of a cavechurch and standing church above, which survived into the thirteenth century (Figure 3). Furthermore, recent palynological analyses and palaeolimnological reconstruction of water bodies conducted by Di Rita \& Magri (2009) and Primavera et al. (2011) of a soil core from the southernmost of the two lakes, showed that from around the eighth century, on the basis of AMS dating of a microcharcoal curve, an increase of fire occurred during a phase of exponential growth of olive (Olea europaea L.), which may reflect a demographic increase and consequent need for more extensive cultivation (Figure 4).

Yet further to the north, between the old Roman town of Lupiae (Lecce) and its port at San Cataldo on the Adriatic, where the remains of an ancient Roman jetty are still to be seen, field survey has again yielded a quantity of small Byzantine farms or villages founded sometime in the eighth or ninth centuries (Arthur, in press). The dating of these sites is based on the presence of ceramics similar to well-stratified examples found at Otranto and at the Deserted Medieval Village (DMV) of Apigliano (Martano), whose chronology is supported by AMS dating, and on the absence of forms that instead became common during the tenth century. The sites represent an increment in the number of settlements with respect to Roman imperial times. Per contra, recent excavations in Lecce itself have produced little in the way of contexts and materials dating between late antiquity and the arrival of the (C) Antiquity Publications Ltd. 


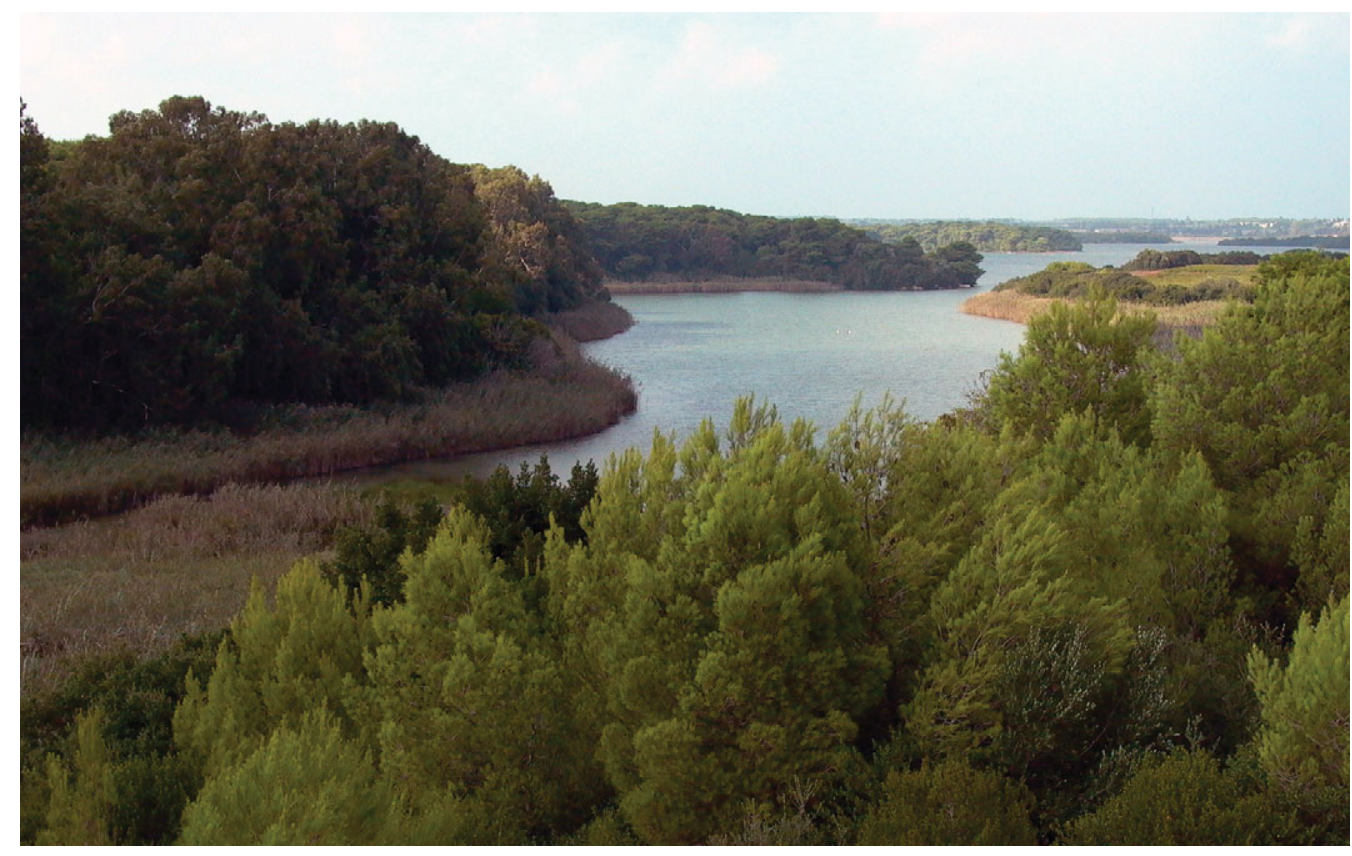

Figure 2. Alimini Grande: the northern lake, looking north.

Normans in the eleventh century, and it has been suggested that a diminished population sought refuge in the old Roman amphitheatre (Fagiolo \& Cazzato 1984: 10).

Data from more surveys and excavations in various parts of the Salento qualify the picture obtained through intensive field survey. A number of modern small towns and DMVs to the west of the Alimini Lakes would appear to have been founded in Byzantine times. These include Cannole and Carpignano Salentino, and the DMVs at Casalino (Cannole), Patolicchie (Melendugno), Ruggiano (Otranto) and Torcito (Cannole). Carpignano Salentino is, indeed, rather well known for possessing the earliest securely dated cave-church in the Salento, with a terminus ante quem provided by a dedicatory wall painting that bears the date AD 959. None of the aforementioned sites appear to have been founded earlier than Byzantine times, and only the DMV of Torlazzo (Otranto), which probably lay along the old road from Lecce to Otranto, has yielded pottery dating from late Roman times until the eleventh century. Further information comes from the DMVs of Apigliano (Martano) and Quattro Macine (Giuggianello), also between Otranto and Lecce, both of which have been subjected to extensive excavations over the last 20 years (Arthur et al. 1996; Arthur \& Bruno 2009). In both cases AMS dating suggests that they were founded as discreet population agglomerates in or around the eighth century, though close to small Roman sites, perhaps farmsteads. The carpological and anthracological remains suggest that land near the village of Apigliano, initially deforested but later left unfarmed, was eventually colonised by post-fire Mediterranean vegetation species (Figure 5). From the tenth-eleventh century, this is increasingly suggested by the presence of holly oak (Quercus cf. ilex), buckthorn/phillyrea (Rhamnus/Phillyrea) and mastic (Pistacia lentiscus L.), reaching

(C) Antiquity Publications Ltd. 


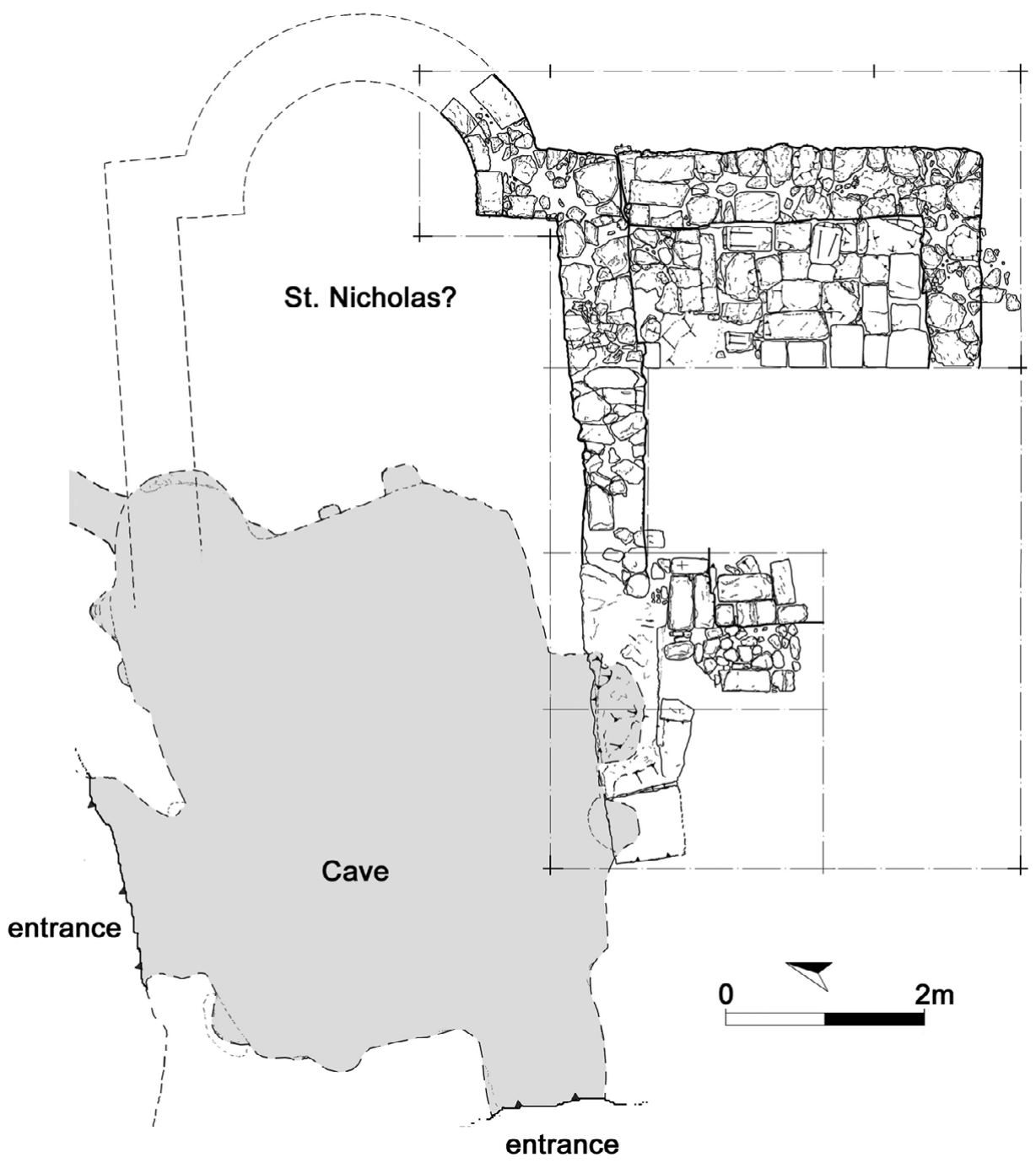

Figure 3. Plan of the church at Pagliarone, overlooking Alimini Grande.

an apparent equilibrium between the agricultural and forested areas. In the early Middle Ages the territory was generally being exploited for olive cultivation, although cereals and pulses were also being cultivated. Of particular note are carbonised wood remains of the carob tree (Ceratonia siliqua L.), unique to Italy at this time (Grasso \& Fiorentino 2009) (Figure 6). Moreover, the proportion of sheep/goat remains in early medieval times is higher ( 72.6 per cent) than from the tenth century onwards ( $<50$ per cent). Perhaps, as more stable conditions were reached, with more land coming under the plough, the number of both cattle and pigs rose in proportion (De Grossi Mazzorin \& De Venuto, in press).

In addition to all this new data that suggests a relatively thriving, if not expanding, settlement system and economy, a unique discovery at another Byzantine village excavation (C) Antiquity Publications Ltd. 


\section{Lago Alimini Piccolo}

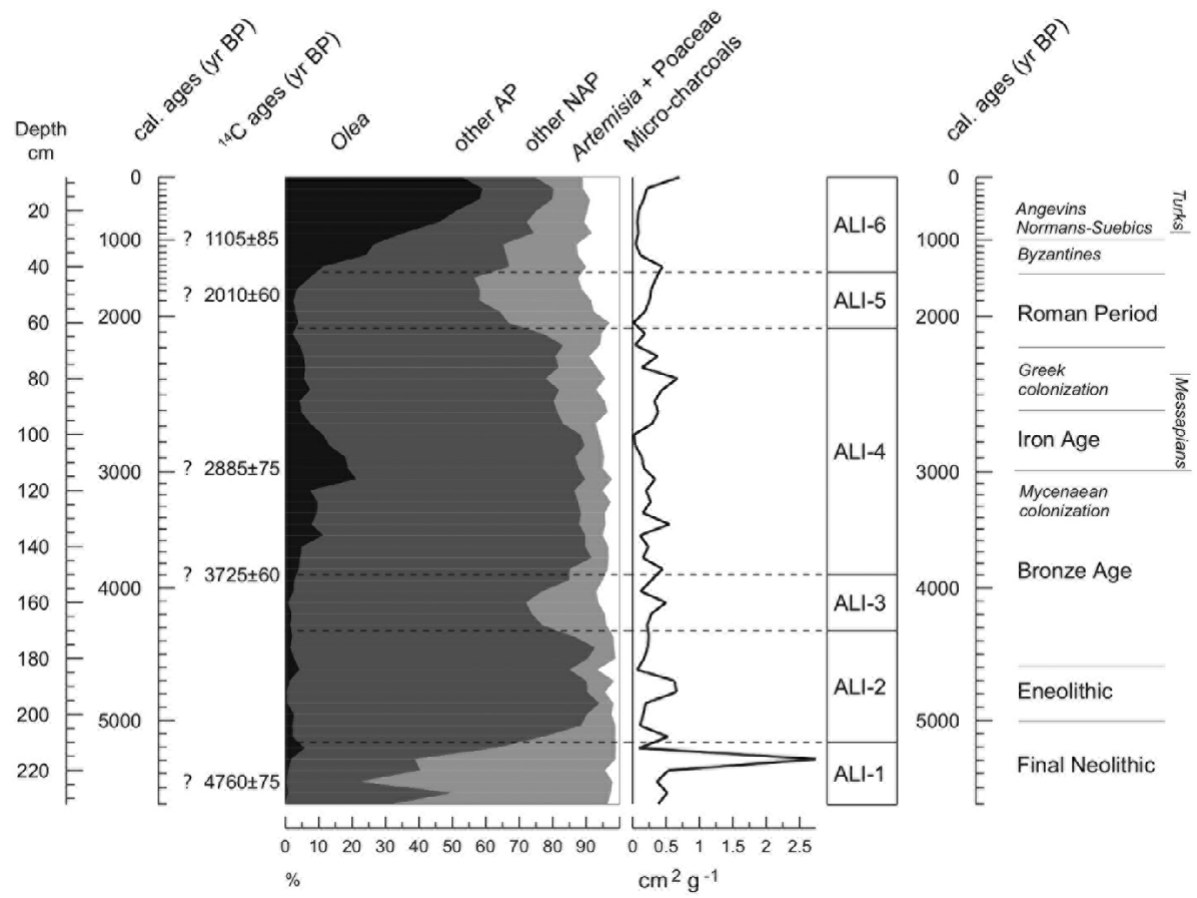

Figure 4. Palynological sequence and microcharcoal record from the Alimini Lakes (from Di Rita \& Magri 2009 modified).

at Loc. Scorpo, north of the modern town of Supersano, enhances our perceptions of agriculture and the landscape in the eighth-century Salento. This briefly-occupied site consists of a number of loosely-grouped sunken-featured buildings interspersed with ditches, which appear to date from the seventh and eighth centuries, ending in the early ninth, at the latest (Figure 7). The site lies on heavy clay deposits, atypical of the area and once prone to flooding, and on the edge of what was once the forest known as the Bosco di Belvedere. In July 2007 a team from the University of Salento excavated an associated well, some $4.50 \mathrm{~m}$ deep, that captured the water-level at a depth of about $3 \mathrm{~m}$. A muddy deposit was encountered below the water table. The last $0.60-0.70 \mathrm{~m}$ of deposit was packed with archaeobotanical remains, as well as a few well-preserved pots that had clearly been lost during attempts to lift water. Three AMS dates suggest that the well was likely to have been abandoned during the eighth century (Arthur et al. 2008).

The numerous archaeobotanical remains include artefacts such as a lathe-turned oak cup, an oak dibber and what appears to have been part of a bow in pear wood (Pyrus sp.), as well as various wooden off-cuts.

The anthracological and carpological remains suggest that there were varied environments around the village. First of all there was a forest characterised by deciduous oak and Mediterranean macchia. The presence of willows (Salix sp.) also indicates that there was an area of high humidity around the village. Finally, plums and pomaceous fruit probably

(C) Antiquity Publications Ltd. 


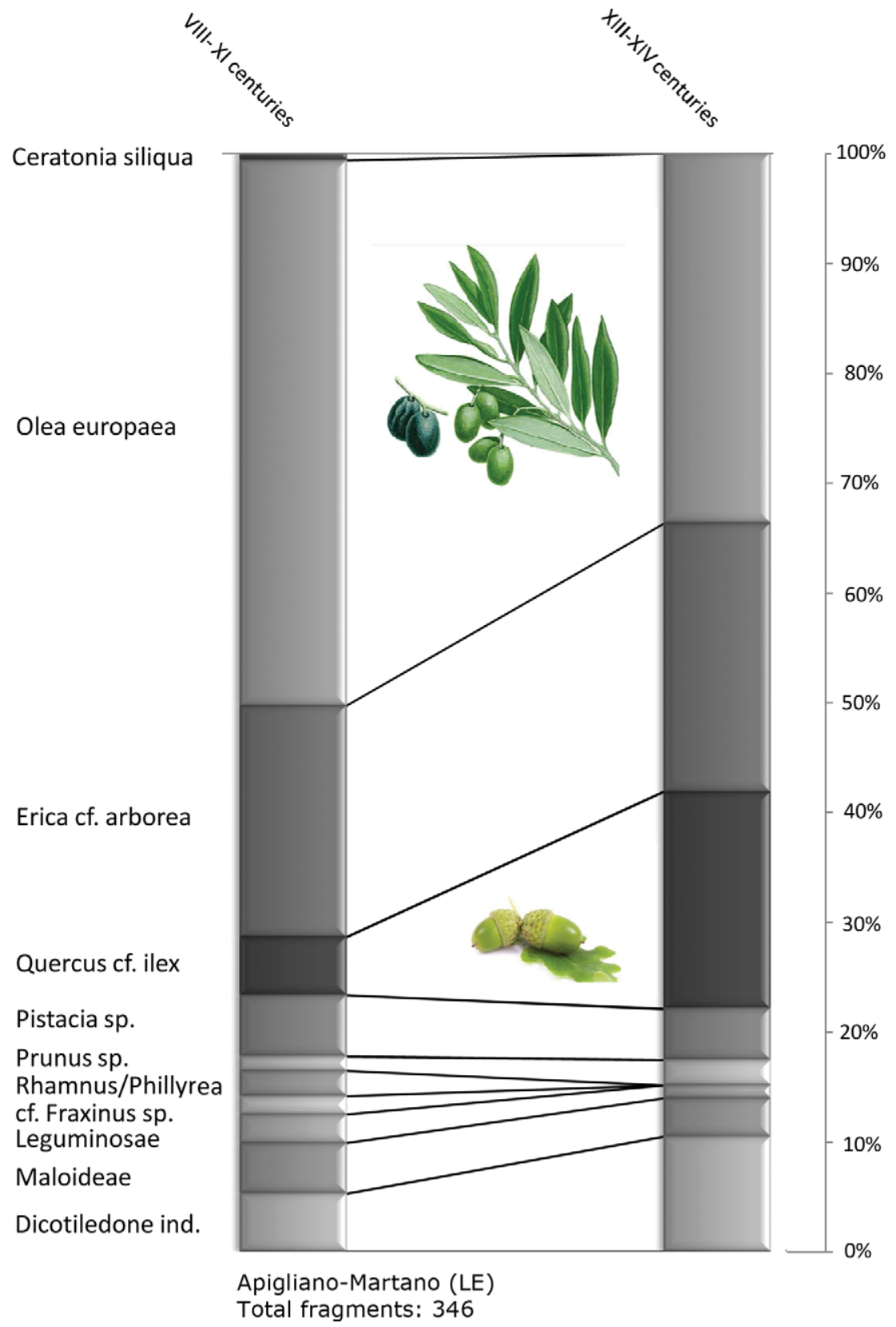

Figure 5. Anthracological diagram for Apigliano.

defined the boundary with the forest. Olive (Olea europaea L.), fig (Ficus carica L.), quince (Cydonia oblonga Mill.), cornelian cherry (Cornus mas L.) and grape (Vitis vinifera L.) were the fruit trees being grown. Of special significance is the identification of over 1200 well-preserved and 227 fragmented grape (Vitis) pips, 1343 pedicels and 148 pressed skins (C) Antiquity Publications Ltd. 


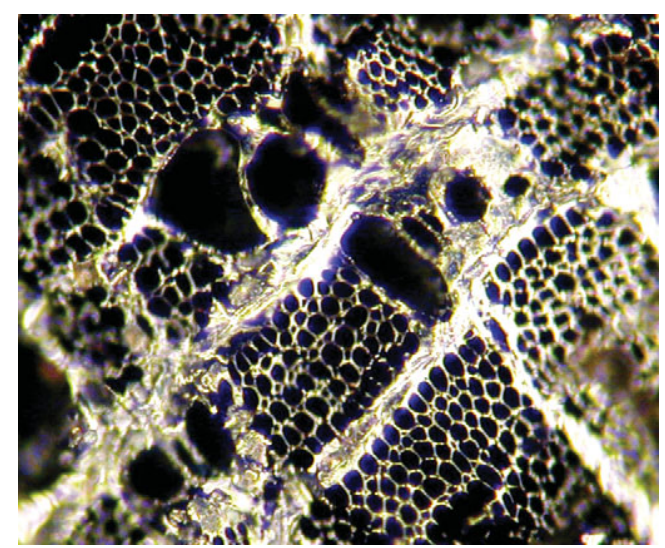

Figure 6. Transverse section of wood charcoal fragment of Ceratonia siliqua (carob tree) $(100 \times$ magnification) from Apigliano.
(Figure 8). The presence of these residues is considered to be direct evidence of pressing, presumably of grapes that were grown locally (see Margaritis \& Jones 2006; Figueiral et al. 2010; Terral et al. 2010), which is also suggested by the residues of pruning of vine branches discovered in the well. Indeed, the discovery of vine remains is especially useful, because the state of conservation of the grape seeds has permitted a series of analyses that would be very difficult, if not impossible, to conduct on carbonised material such as is usually found in archaeological contexts in the Mediterranean area. A representative sample of grape seeds has been subjected to morphological and morphometric examination through image analysis and the numerical elaboration of the resulting profiles, with the aim of identifying eventual morphological characteristics of grape varieties such as would further permit us to hypothesise possible routes and modes of exchange or transport of the grape in the Mediterranean basin. A limited sample, subjected to both proteomic and genetic analyses, has revealed the presence of proteins and fragments of aDNA that have been compared with a database of present varieties of grape. Together with the morphological analyses, the DNA profile obtained from one of the seeds appears to provide important indications on the Aegean origin of the variety of grape unearthed at Supersano (Cappellini et al. 2010). Indeed, it is its affinity with modern Greek cultivars that suggests the cultivation of similar varieties of grape in both areas by Byzantine times, if not earlier.

Last but not least, the excavations yielded cereals such as wheat (Triticum sp.), barley (Hordeum vulgare L.) and oats (Avena sp.). The further identification of numerous bur clover (Medicago polymorpha L.) legumes suggests that close to the village lay alternating cultivated and fallow areas, the latter to provide for animal fodder.

\section{Discussion}

Although we are still a long way from reconstructing the Byzantine and medieval landscape of the Salento (Figure 9), the parcels of Roman centuriation that survive down to this day, taken together with those portions that have disappeared, may be an indication of areas of differential agrarian continuity and demographic survival (Arthur, in press). Medieval toponyms help further in assessing old cultivated areas and zones of forest, Mediterranean macchia or shrubland, and marsh. The picture that is now emerging is that of a dynamic landscape that, before the year $\mathrm{AD} 1000$, was on the way to recovery from the crises of the sixth and seventh centuries that witnessed depopulation, settlement desertion and economic collapse in the wake of Justinian's 20-year war of reconquest, bubonic plague and the Lombard invasion of Italy. Perhaps with the disappearance of such regulatory

(C) Antiquity Publications Ltd. 


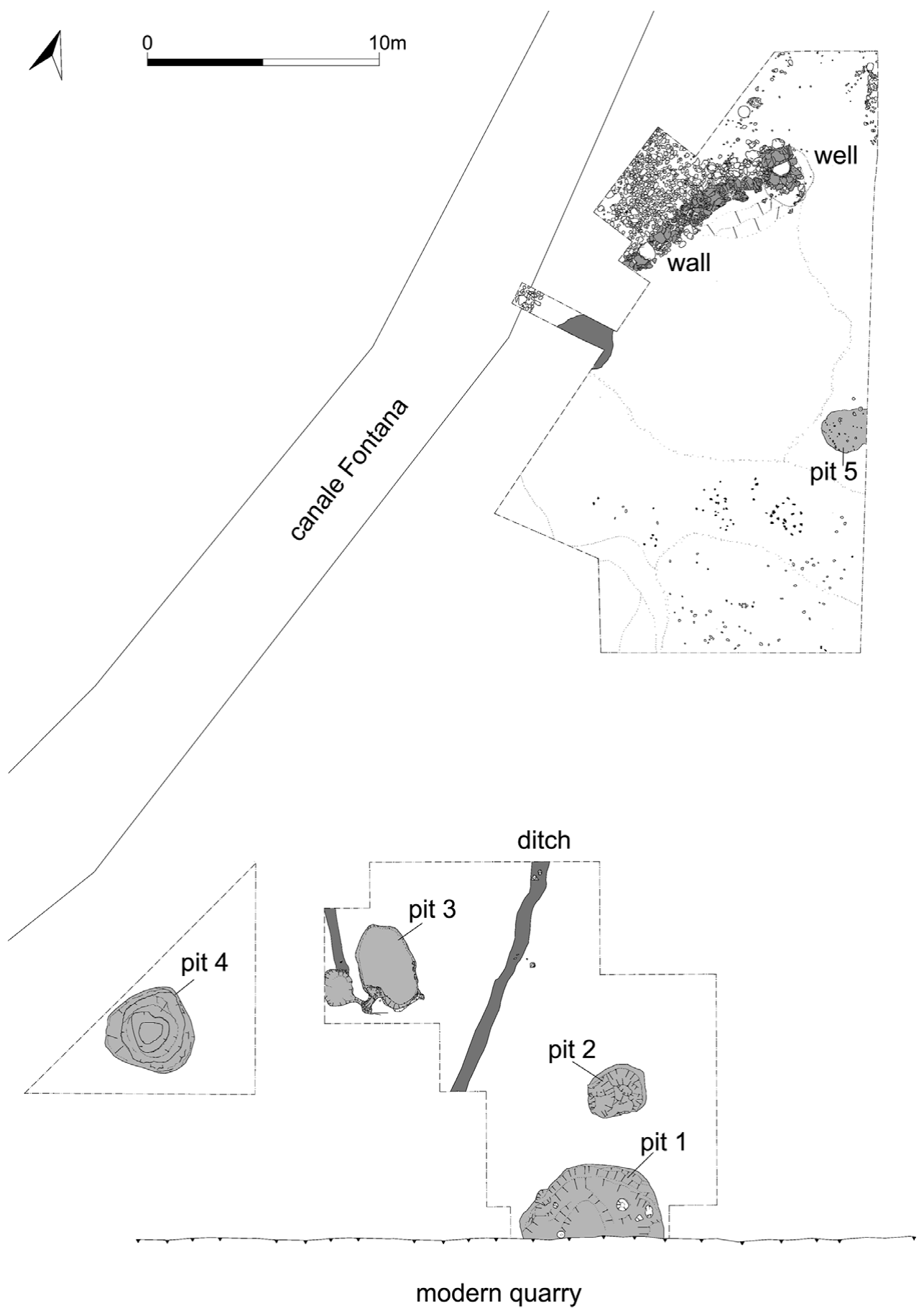

Figure 7. Plan of the excavated features of the Byzantine settlement at Supersano.

(C) Antiquity Publications Ltd. 

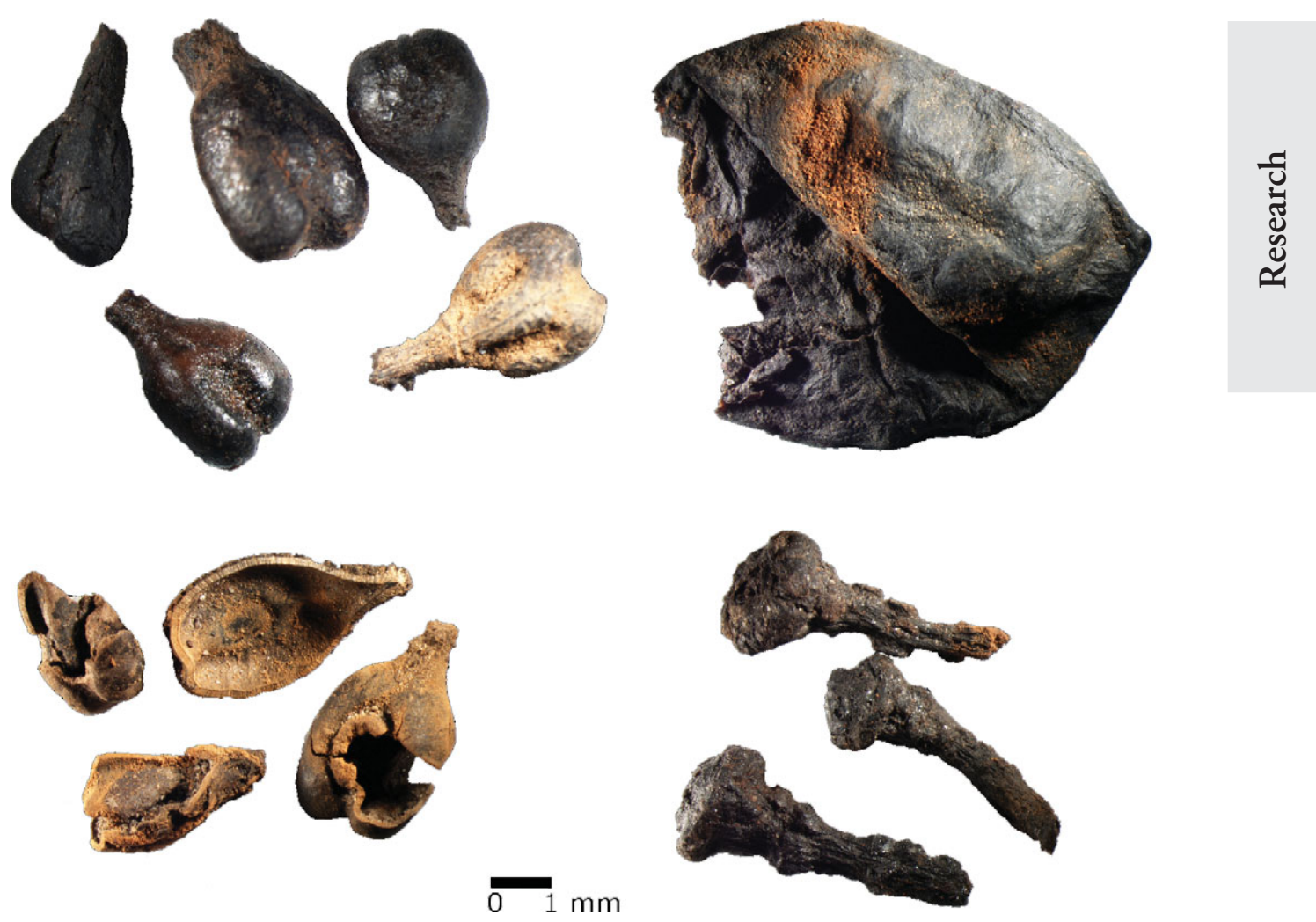

Figure 8. Waterlogged grape remains (pips, skin and pedicels) from Supersano.

mechanisms such as the plague (and malaria?) on population figures, together with climatic amelioration, the population was permitted to develop and grow in a relatively favourable environment. Indeed, both the archaeobotanical and faunal data from Supersano show the potential for a varied and, arguably, quite balanced human nutrition in early medieval times, despite, or perhaps because of, the absence of access to Mediterranean-wide markets, which may have conditioned consumption in earlier and later times. Recent studies by Barbiera \& Della-Zuana (2009) suggest that we might reconsider what has often been seen as a negative state of health of early medieval populations. Furthermore, research on climatic reconstruction through dendrochronology is helping to nuance the picture of historical development (Büntgen et al. 2011).

In the eighth century, a warmer climate and more rain than in the preceding century, coupled with the strategic position of the Salento, both politically and commercially, between east and west, north and south, is likely to have boosted recovery in southern Apulia. Recovery at this time is now suggested by the ever-increasing archaeological data. It is perhaps no coincidence that the area was also subjected to Saracen raids in the search for slave labour in the eighth century and, even more so, during the ninth, indicating the existence of a suitable demographic reservoir. Although historical sources referring to raids are few (including a severe assault on the territory of Ugento in $\mathrm{AD} 876$, with deportation

(C) Antiquity Publications Ltd. 


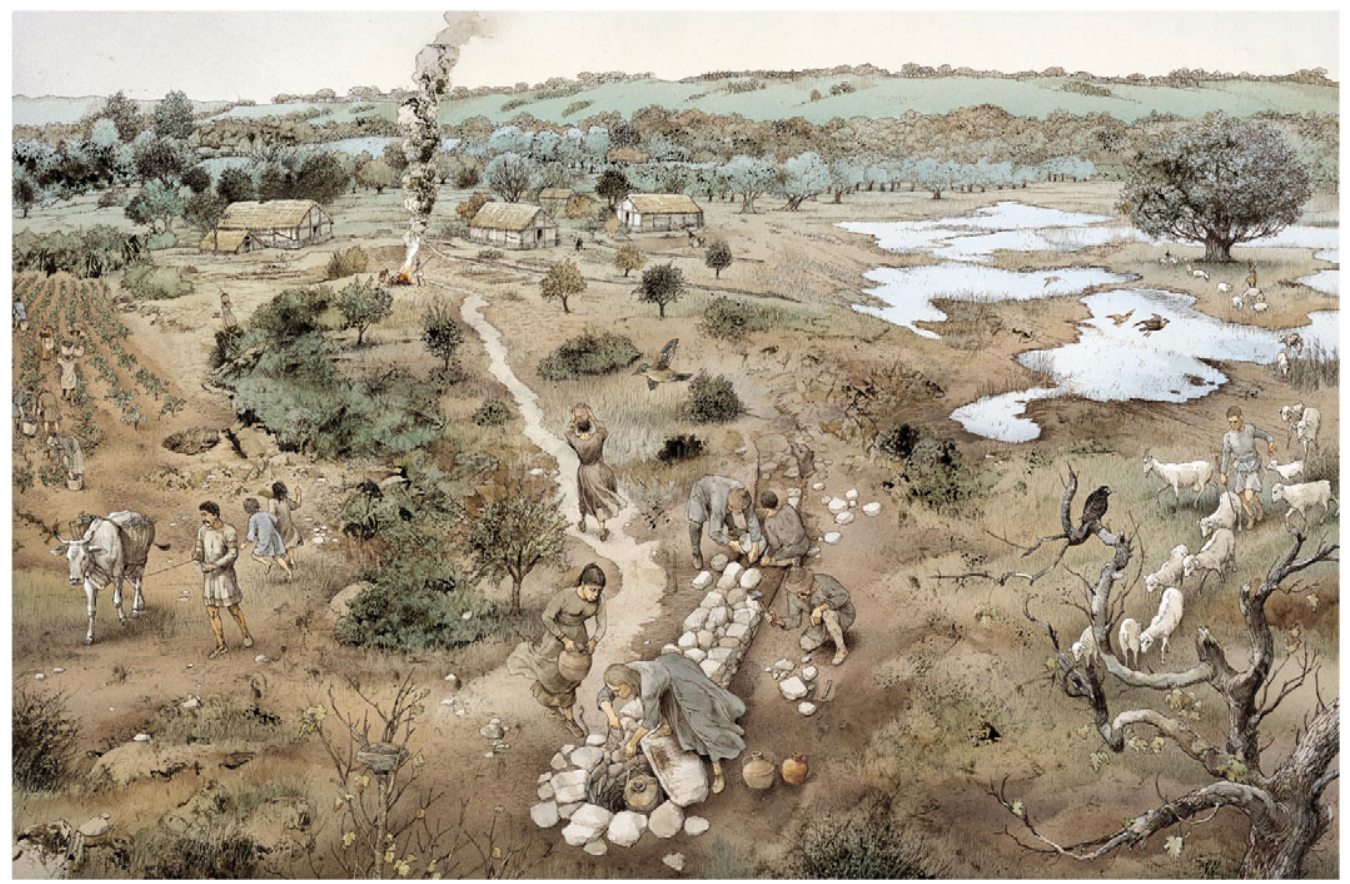

Figure 9. Reconstruction of the Byzantine village at Supersano (Inklink, Florence).

to Carthage, and almost 40 years of Arab occupation of Taranto in the ninth century), they are powerfully supported by numerous local traditions (Arthur 2003).

Even if the chronology of recovery varies from area to area across the Mediterranean, influenced by local and global, natural and anthropic phenomena, it is worth observing how part of a relatively outlying province of the Byzantine empire is now eloquently demonstrating, through archaeology, its potential in the reconstruction of the Mediterranean economy from the early medieval depression to the later medieval agricultural revolution.

\section{Acknowledgements}

This paper would not have been possible without the assistance of numerous students and colleagues. We hope that they will bear with us, as we shall thank them all personally in project and site reports. Observations by the two anonymous reviewers have further improved our text.

\section{References}

ARTHUR, P. 2003. Saraceni, schiavi e il Salento, in P. Peduto \& R. Fiorillo (ed.) III Congresso nazionale di archeologia medievale: 443-45. Firenze: All'Insegna del Giglio.

- In press. Villages, communities, landscapes, in the Byzantine and medieval Salento, in P. Galetti (ed.) Villaggi, comunità, paesaggi medievali. Spoleto: Centro italiano di studi sull'alto medioevo.
Arthur, P. \& B. Bruno (ed.). 2009. Apigliano. Un villaggio bizantino e medievale in Terra d'Otranto. L'ambiente, il villaggio, la popolazione. Galatina: Arti Grafiche Panico.

Arthur, P., U. Albarella, B. Bruno \& S. King. 1996. 'Masseria Quattro Macine' a Deserted Medieval Village and its territory in southern Apulia: an interim report on field survey, excavation and document analysis. Papers of the British School at Rome 64: 181-238.

(C) Antiquity Publications Ltd. 
Arthur, P., G. Fiorentino \& M. Leo Imperiale. 2008. L'insediamento in Loc. Scorpo (Supersano, LE) nel VII-VIII secolo. La scoperta di un paesaggio di età altomedievale. Archeologia Medievale 35: 365-80.

Barbiera, I. \& G. Della-Zuana. 2009. Population dynamics in Italy in the Middle Ages: new insights from archaeological findings. Population and Development Review 3-5(2): 367-89.

Bethmann, L.K. \& G. Waitz (ed.). 1878. Pauli Diaconi, Historia Langobardorum, in M.G.H. Scriptores Rerum Longobardicarum et Italicarum. Hannover.

Brubaker, L. \& J. Haldon. 2011. Byzantium in the iconclast era c. 680-850: a history. Cambridge: Cambridge University Press.

Büntgen, U., W. Tegel, K. Nicolussi, M. McCormick, D. Frank, V. Trouet, J.O. Kaplan, F. Herzig, K.-U. Heussner, H. Wanner, J. LUTERBACHER \& J. ESPER. 2011. 2500 years of European climate variability and human susceptibility. Science 331(6017): 578-82.

Cappellini, E., M. Thomas, P. Gilbert, F. Geuna, G. Fiorentino, A. Hall, J. Thomas-Oates, P.D. Ashton, D.A. Ashford, P. Arthur, P.F. CAmpos, J. KoOl, E. Willerslev \& M.J. Collins. 2010. A multidisciplinary study of archaeological grape seeds. Naturwissenschaften 97: 205-17.

De Grossi Mazzorin, J. \& G. De Venuto. In press. L'economia produttiva animale: i risultati delle analisi archeozoologiche, in P. Arthur, M. Leo Imperiale \& M. Tinelli (ed.) Apigliano. Un villaggio bizantino e medievale in Terra d'Otranto. La cultura materiale. Galatina: Arti Grafiche Panico.

Di Rita, F. \& D. MAGri. 2009. Holocene drought, deforestation, and evergreen vegetation development in the central Mediterranean: a 5,500 year record from Lago Alimini Piccolo, Apulia, southeast Italy. The Holocene 19: 295-306.
Fagiolo, V. \& M. Cazzato. 1984. Lecce. Rome-Bari: Laterza.

Figueiral, I., L. Bouby, L. Buffat, H. Petitot, J.F. TERRAL. 2010. Archaeobotany, vine growing and wine producing in Roman southern France: the site of Gasquinoy (Béziers, Hérault). Journal of Archaeological Science 37(1): 139-49.

Grasso, A.M. \& G. Fiorentino. 2009. L'ambiente vegetale: risultati delle nuove analisi archeobotaniche, in P. Arthur \& B. Bruno (ed.) Apigliano. Un villaggio bizantino e medievale in Terra d'Otranto. L'ambiente, il villaggio, la popolazione: 53-56. Galatina: Arti Grafiche Panico.

HoCKer, F.M. 1998. Bozburun Byzantine shipwreck excavation: the final campaign, 1998. Institute of Nautical Archaeology Quarterly 25(4): 3-13.

MARGARITIS, E. \& M. Jones. 2006. Beyond cereals: crop-processing and Vitis vinifera L.: ethnography, experiment and charred grape remains from Hellenistic Greece. Journal of Archaeological Science 33: 784-805.

Primavera, M., O. Simone, G. Fiorentino \& M. CALDARA. 2011. The palaeoenvironmental study of Alimini Piccolo lake enables a reconstruction of Holocene sea-level changes in southeast Italy. The Holocene 21(4): 553-63.

Terral, J.F., E. Tabard, L. Bouby, S. IVorra, T. Pastor, I. Figueiral, S. PicQ, J.B. Chevance, C. Jung, L. Fabre, C. Tardy, M. Compan, R. BACILIERI, T. LACOMBE \& P. This. 2010. Evolution and history of grapevine (Vitis vinifera) under domestication: new morphometric perspectives to understand seed domestication syndrome and reveal origins of ancient European cultivars. Annals of Botany 105(3): 443-55.

Von Falkenhausen, V. 2007. Tra Occidente e Oriente: Otranto in epoca bizantina, in H. Houben (ed.) Otranto nel Medioevo tra Bisanzio e l'Occidente: 13-60. Galatina: Congedo.

Received: 29 June 2011; Accepted: 5 October 2011; Revised: 5 December 2011

(C) Antiquity Publications Ltd. 